\title{
The Employee Engagement Framework: High Impact Drivers and Outcomes
}

\author{
Amena Shahid \\ Professor, Pilon School of Business \\ Sheridan College Institute of Technology and Advanced Learning \\ Hazel McCallion Campus, 4180 Duke of York Blvd Mississauga, Ontario L5B 0G5, Canada \\ Received: March 1, 2019 Accepted: April 21, $2019 \quad$ Published: April 21, 2019 \\ doi:10.5296/jmr.v11i2.14612ＵRL: https://doi.org/10.5296/jmr.v11i2.14612

\begin{abstract}
For the prior two decades, employee engagement has been a subject of interest both in academic research and among managers. Organizations have invested vital resources in promoting employee engagement since employee engagement is identified as a critical driver of organizational performance. Engagement adds distinctly to an organization's performance, driving to gains in quality, customer satisfaction, and long-term monetary results. In a world that is evolving both regarding the global essence of work and the diversity of the employees, engaged employees may be a core of an ambitious resource. Companies promoting employee engagement will achieve organizational goals effectively. Several employees look for settings where they can be engaged and know that they are participating positively. The paper presents the employee engagement framework enabling organizations to understand how engagement may differ by employee or group and recognize the key drivers that impact engagement at the workplace.
\end{abstract}

Keywords: Employee engagement, performance, human resources, drivers of engagement 


\section{Introduction}

The value of employee engagement cannot be amplified - employee engagement approaches determined to lower staff turnover, increase productivity and performance, retain customers at a leading speed, and lastly added profits. Engaged employees are contented, both at work and in their personal lives. When competition for the best talent is tight, and the cost of training new recruits is sheer, organizations cannot allow not to engage employees. Also, they are the organization's ambassadors. Companies have tried with recreational strategies to employee engagement. Employee engagement requires to be an element of an integrated business plan designed to engage staff in the spirit of the company.

Employee engagement is one of the critical factors of an organization's achievement as well as the thriving implementation of distinct effective changes. Wellins and Concelman (2005) determined employee engagement as a place where motivated employees achieve high performance through promoting commitment, integrity, productivity, and ownership. According to Richman (2006), employees' engagement is a passionate and intelligent commitment to the organization. Robinson, Perryman, and Hayday (2004) reported employees' engagement as a collection of positive opinions towards the organization's administration and benefits. For Madan and Srivastava (2015), employee engagement points to 'commitment' and drive to go ahead the call of duty towards the organization's purposes, whereas employee satisfaction relates to 'contentment.' Ghuman (2016) identified employee engagement as the readiness and energy contributing to company achievement with more effort on a continuous basis. According to Towers Perrins Report on employee engagement (2003), promoting employee engagement is a manner that never stops and deeply enhances work experience. It is not about getting people happy or rewarding them more money. Havill (2010) denoted that understanding the level of employees' engagement in the organization is the basis for change and its progress. Litten et al. (2011) (as cited in Madan and Srivastava, 2015) point out that employee engagement is a different and vigorous process that represents each person's individual, own connection with work.

\section{Literature Review}

Employee engagement was a familiar concept in the industry during the period 1999-2005 where it was widely talked among managers, consultants, and policymakers. In a study of 2,564 U.S. managers, Gallup research discovered that just 35\% are engaged, while $51 \%$ are not engaged and 14\% are actively disengaged. By Gallup's measures, the "not engaged" group costs the U.S. $\$ 77$ billion to $\$ 96$ billion annually through their influence on those they manage (Adkins, 2015). Gallup's State of the Global Workplace report 2017 reveals 15\% of employees worldwide are engaged in their jobs (State of the Global Workplace, 2017).

Gallup asked the engagement questions worldwide and discovered that between 2015 and 2016 , out of the 1.4 billion adults who have good jobs, roughly $16 \%$ are engaged (State of the Global Workplace, 2017). 68\% of executives think their employees would be more engaged in their job and achieve at more significant levels if they had opportunities to be challenged by working on meaningful projects inside and outside the company (Covestro, April 5, 2018). 


\section{Mll Macrothink}

Journal of Management Research

ISSN 1941-899X

2019, Vol. 11, No. 2

According to the AON 2018 Trends in Global Employee Engagement, the story in Latin America is not that engagement remained flat rather decreased in some key markets. The region's topmost drivers of engagement are senior leadership, career \& development, rewards $\&$ recognition, talent \& staffing, and enabling infrastructure (AON, 2018). The report also described engagement in Europe has been jumping back and forth between 58\% to $60 \%$ since 2014 and has frequently improved since 2011. Lastly, the report also implied that the most significant increase for a region belongs to Africa, where engagement grew from $6 \%$ of employees to $66 \%$. Employee engagement is about communication of expectations between employer and employee, and the distributed support of an organizational culture of trust by the team. It is a general perception of a vast majority of leaders that the employees are a company's most valuable resource. But in fact, that is merely true when the majority of the workforce is wholly engaged in their work. If not, they are either continuing least value or actively operating against the organization.

\section{New Framework of Employee Engagement}

Poor employee engagement in the workplace can be a hurdle for many organizations today. Businesses need to engage with their staff to have their workforce motivated and productive. It is imperative for organizations to strive to create an engaged, high-performing and reliable workforce. Recognizing and resolving the difficulties connected with employee engagement can support in attaining this aim. Companies investing in higher-trained and more service-oriented workforces have a notable effect on profitability and growth. With growing competition, technological progress and globalization organizations have begun to recognize that employees are the presentation of the business and roots of change and organizational culture. The employee-work agreement has modified: People are working more like an independent resource than in the past. In short, the strength has driven from employer to employee, requiring business leaders to determine to institute an organization that engages employees as sensible, inspiring, and productive contributors. Keeping that in mind a new employee engagement framework is presented. This framework proposes a new model of employee engagement, along with its drivers and outcomes.

The research shows that employee engagement is a summation of several drivers. A manager will apply some of these drivers to influence employees' engagement. The result of these drivers does not occur in isolation; the company's circumstances and culture will decrease or increase their influence on employee engagement.

\subsection{A Positive Working Culture}

Evidence shows a positive work environment raises productivity, thereby creating a more profitable business. A positive workplace culture encourages employee engagement, which promotes the bottom line. "Engaged employees deliver better business outcomes than other employees - over the industry, company size and nationality, and in sound economic times and bad," (Harter and Mann, 2017). According to Schein (1990), organizational culture is where shared values and practices of the people are regarded as a means that drives the achievement of organizational goals. Employee engagement is a primary result of high-performance company culture as it only draws behaviors and standards that are healthy 
and reassuring. Employees distinctly recognize their culture and expectations. They feel connected and engaged. The organization culture requires constant improvement for long-term benefit. The organizations investing in better working culture perceive rising employee engagement.

Table 1. Employee Engagement Drivers and Outcomes

\begin{tabular}{|l|l|}
\hline \multicolumn{1}{|c|}{ Engagement Drivers } & \multicolumn{1}{c|}{ Strategic Outcomes } \\
\hline A Positive Working Culture & - Flexible and Supportive work environment \\
& - Relaxed, Collaborative and Happy employees \\
& - Fosters positive social relations \\
\hline - Boosts commitment and performance
\end{tabular}

\subsection{Inspiring Leadership}

Harvard Business School collected data from assessments of more than 50,000 leaders, and the strength to inspire endured as one of the primary competencies. It is the quality generating the immense employee engagement, it is what divides the real leaders from everyone else, and it is what employees want most in their leaders ( Zenger, Folkman, 2013). The inspirational leaders kindle a fire within their employees and followers that drive them to act. These leaders are highly collaborative. They work beside their people to perform, supports to 
imagine endless opportunities, invest and promote actions cultivating physical, intellectual, emotional, and spiritual growth \& well-being and use communication as a reason to growth and strategic tool to achieve their goals.

\subsection{Meaningful Work}

Meaningful work has been continuously identified as a fundamental employee engagement driver. A study led by Professor Catherine Bailey reveals how employees discover meaning in their work. When employees were questioned about meaningful times at work, very few stated effective leadership. But poor leadership was connected with diminishing meaningfulness ( Bailey and Madden, 2016). Employees crave to know their work serves others, not just themselves. Leaders and managers real and open conversations with employees help to understand the connection between work and personal life values. According to the researchers, there has been a constant rise in research into meaningfulness, engagement and commitment at work (Dik \& Duffy, 2008; Hult, 2005; Schaufeli \& Bakker, 2004). Meaningful work can produce gains for organizations and lead to positive work results such as satisfied, engaged and invested employees, personal and organizational satisfaction, productivity, retention, and loyalty.

\subsection{Professional Development}

Career development is a valuable approach to engage employees. Investing time and money in employees advocates engaging them with the business. Recognizing individual expertise and giving career development opportunities for employees to advance their skills is a significant element in a sound talent management strategy. It does wonders in engaging the existing workforce while also hiring and retaining future employees. Learning in the workplace is an investment supporting companies retain and engage employees. According to Deloitte University Press research, More than two-thirds [of millennials] think it is management's responsibility providing accelerated development opportunities (Bersin, 2015). Workers believing in not developing their skills are more likely to leave the company than those learning new information and advancing their careers consistently.

\subsection{Freedom: Sense of Autonomy}

Job autonomy has been positively linked with employee engagement (Saks, 2006; Shantz, Alfes, Soane, \& Truss, 2013; Yong, Abdullah, Rahman. \& Nik Mat, 2013). Based on a study conducted by Yong et al. (2013) in the Malaysian private sector, the grant of autonomy at work serves as an incentive to employees who may realize a sense of return by giving higher levels of engagement in their jobs. When the organization decays to promote these job attributes or offers support to complete tasks; employees are more likely to withdraw and disengage from their roles (Saks, 2006). Acknowledging that job autonomy follows a positive connection with the engagement and it works as an antecedent of commitment, there is a chance that the outcome of employees' see job autonomy on commitment is dependent on their engagement levels.

Studies have discovered a positive relationship between transformational leadership style and employee engagement (Lockwood, 2007; Seijts \& Crim, 2006). Managers practicing 
transformational leadership style lead to empowering their subordinates with more autonomy in their work and this finally creates subordinates to develop a higher sense of their work (Schaufeli \& Bakker, 2004). Job autonomy has to grow with opportunities for employees receiving and providing feedback about job-related matters for them to be engaged and committed to the organization. While engaging with possible employees, both during the interview stage and as part of the on-boarding process, autonomy should be central to the messaging and employer branding. Building a company culture with autonomy rooted at its heart needs proper messaging from the very start of the employee/employer relationship.

\subsection{Recognition}

Employee engagement mirrors the level of commitment employees exhibit toward their employers and their jobs. The higher the level of engagement, the employee will work the extra mile to perform well and be a promoter for the company. Employees always feel a lot more appreciated when their managers mention their hard work and see their jobs and the workplace more pleasant as a result. Satisfied workers drive to more positive company culture. An improved culture increases employees motivation, innovation, productivity, and engagement. The appreciated team feels that they are part of an organization that cares about its employees and their commitment. Firms that recognize their team members lead a definite prominence as being a great place to work. Employees speak about their company fairly to others, which is better branding and drawing top talent for hiring.

A report by the Society of Human Resource Managers(2015), explained the influence of recognition on employee engagement. It determined that companies with employee recognition programs and excellent career development direction observed a 63 percent increase in employee productivity, a 58 percent profit on their profit margins, a 52 percent rise in customer retention, and a 51 percent boost in employee retention.

\section{The New Framework Impact on Business Performance}

In today's business context, organizations must gain the most of each worker. One way to make this occur is to place the drive into developing a collaborative relationship between the employee and the employer. If workers sense they are valued, they are more inclined to do their best work. To optimize the use of every worker, organizations take proper attention at employee engagement. Highly engaged employees are best performers, working as advocates of the company and adding confidently to the bottom line business success. Valuable research showed by the management and behavioral sciences supporting the theory that when employees are engaged, service quality, customer satisfaction, employee retention, productivity, and financial achievement improve (Harter, Schmidt, \& Hayes, 2002). When employees are separated or disengaged, organizations experience deteriorations in all of these areas.

Research and practice in employee engagement developed and evolved for over 25 years. But where precisely do employee engagement applications hold today? To find out, HR.com surveyed 717 members of their organization who are in the HR profession and relevant fields. The survey showed that over $90 \%$ of respondents believe there is substantial evidence linking 
engagement to performance and most participants believe less than $70 \%$ of their employees are engaged (The State of Employee Engagement in 2018). According to Gallup 2018 report, $87 \%$ of employees worldwide are not engaged (The Engaged Workplace, 2018).

Employee engagement is a prime business preference for senior executives. Business leaders understand that having high-performing employees is crucial for growth and continuation. The proposed framework recognizes an engaged workforce strengthening innovation, productivity, and bottom-line achievement with diminishing costs linked to hiring and retention in extremely ambitious talent markets. Providing employees with the energy to enhance the customer's experience is as essential as the reputation and bottom lines of business. The perspectives of frontline staff are a result of their engagement. Employees are more customer focused when engaged (Harter, 2009) as they are driven to improve their discretionary effort managing the success of the business, rather than merely for personal gain. The engaged staff has a positive impact on an organization's standing in the broader world by being brand ambassadors.

The researchers noted that organizations experience 26 percent higher revenue per employee when employees are highly engaged (Taleo Research, 2009). Moreover, it was determined that organizations with highly engaged employees earned 13 percent greater total returns to shareholders (Taleo Research, 2009). Furthermore, a meta-analysis (Harter et al., 2002) recorded that businesses in the top $25 \%$ for employee engagement (of those studied) produced up to four percentage points in profitability. Research by Towers Perrin (2003) shows that the more engaged employees at an organization are, the more apt it is to outperform the industry average in one-year revenue growth.

\section{Conclusion}

High-performing companies recognize and respond to non-performance before there is an economic rationale to do so. The key is to engage and empower the employees who are committed and work on the engagement levels of others. Organizations reaching the desired strategic outcomes realize diverse drivers of engagement influence different employees. The framework gives a depth of engagement, along with relevant measures of the drivers, and the results of the engagement. Therefore, organizations using this framework will know which drivers have a noticeable impact on employee engagement for different employees and the relationship between employee engagement and strategic outcomes.

\section{References}

Adkins, A. (2015, April). Only 35\% of U.S. Managers Are engaged in their jobs. The Gallup Organization.

Retrieved

from

https://www.gallup.com/workplace/236552/managers-engaged-jobs.aspx

Alan M. S, (2006). Antecedents and consequences of employee engagement. Journal of Managerial Psychology, 21(7), 600-619. https://doi.org/10.1108/02683940610690169 
AON Report. (2017). Trends in global employee engagement 2018. Retrieved from https://www.aonhewitt.com.au/AON.Marketing/media/Australia/pdf/Resources/Reports\%20a nd\%20research/2018-Trends-in-Global-Employee-Engagement.pdf

Bailey, C., \& Madden, A. (2016). What makes work meaningful -- or meaningless. MIT Sloan Management Review, 57(4), 53-61. Retrieved from https://search-proquest-com.library.sheridanc.on.ca/docview/1802194552?accountid=3455

Berson, J. (2015, January). Becoming irresistible: A new model for employee engagement. Deloitte Insights. Retrieved from https://www2.deloitte.com/insights/us/en/deloitte-review/issue-16/employee-engagement-stra tegies.html

$\begin{array}{lllll}\text { Covestro } & \text { i3 } & \text { Index. } & \text { (2018). } & \text { Retrieved }\end{array}$ https://www.covestro.us/csr-and-sustainability/i3/covestro-i3-index

Dik, B. J., \& Duffy, R. D. (2009). Calling and vocation at work: Definitions and prospects for research and practice. The Counseling Psychologist, 37(3), 424-450. https://doi.org/10.1177/0011000008316430

Ghuman, K. (2016). A prognostic examination of functional and emotional employee engagement drivers and their impact on employee performance. FIIB Business Review, 5(2), $78-87$.

Harter, J. K., Schmidt, F. L., \& Hayes, T. L. (2002). Business-unit-level relationship between employee satisfaction, employee engagement, and business outcomes: A meta-analysis. Journal of Applied Psychology, 87(2), 268-279. https://doi.org/10.1037/0021-9010.87.2.268

Harter, J.K., Schmidt, F.L., Killan, E. A., \& Agrawal. S. Q12 meta-analysis:The relationship between engagement at work and organizational outcomes. White Paper Gallup Organization, 2009. Retrieved on from http://www.gallup.com/consulting/126806/q12-meta-analysis.aspx on 10 June

Harter, J., \& Mann. A. (2017, April). The right culture: Not just about employee satisfaction. The Gallup Organization. Retrieved from https://www.gallup.com/workplace/236366/right-culture-not-employee-satisfaction.aspx

Havill, L. (2010). A new type of engagement. The CPA Journal, 80(7), 14. Retrieved from https://search-proquest-com.library.sheridanc.on.ca/docview/637269875?accountid=3455

Hult, C. (2005). Organizational commitment and person-environment fit in six Western countries. Organization Studies, 26(2), 249-270. https://doi.org/10.1177/0170840605049800

Industry research: A report card on employee engagement in 2018. (2018, 04). Recognition and Engagement Excellence Essentials. Retrieved from https://search-proquest-com.library.sheridanc.on.ca/docview/2043342595? accountid=3455

Litten, J. P., Vaughan, A. G., \& Wildermuth, C. D. (2011). The fabric of engagement: The engagement and personality of managers and professionals in human and developmental 
disability services. Journal of Social Work in Disability \& Rehabilitation, 10(3), 189-210. https://doi.org/10.1080/1536710X.2011.596447

Madan, Poornima \& Srivastava, Shalini. (2017). Investigating the role of mentoring in managerial effectiveness-employee engagement relationship: an empirical study of Indian private sector bank managers. European Journal of Cross-Cultural Competence and Management, 4(2), 146-167. https://doi.org/10.1504/EJCCM.2017.083809

Richman, A. (2006). Everyone wants an engaged workforce how can you create it?. Workspan, 49,36-39

Robinson, D., Perryman, S. and Hayday, S. (2004) The Drivers of Employee Engagement Report (Report No. 408). Retrieved from https://www.employment-studies.co.uk/system/files/resources/files/408.pdf

Schaufeli, W. B., \& Bakker, A. B. (2004). Job demands, job resources, and their relationship with burnout and engagement: A multi-sample study. Journal of Organizational Behavior, 25(3), 293-315. https://doi.org/10.1002/job.248

Schein E.H. (1990) Organizational culture. American Psychologist, 43, 109-119. https://doi.org/10.1037/0003-066X.45.2.109

Seijts, G. H., \& Crim, D. (2006). What engages employees the most or, the ten C's of employee engagement. Ivey Business Journal, 70, 1-5. Retrieved from https://search-proquest-com.library.sheridanc.on.ca/docview/216175829?accountid=3455

Shantz, A., Alfes, K., Truss, C., \& Soane, E. (2013). The role of employee engagement in the relationship between job design and task performance, citizenship and deviant behaviours. International Journal of Human Resource Management, 24(13), 2608-2627. https://doi.org/10.1080/09585192.2012.744334

Society for Human Resource Management. (2015). Employee job satisfaction and engagement: Optimizing organizational culture for success. Retrieved from https://www.shrm.org/ResourcesAndTools/business-solutions/Documents/2015-job-satisfacti on-and-engagement-report.pdf

Swarnalatha, C., \& Prasanna, T. S. (2013). Leveraging employee engagement for competitive advantage: Strategic role of HR. Review of HRM, 2, 139-148. Retrieved from https://search-proquest-com.library.sheridanc.on.ca/docview/1655997743?accountid=3455

Taleo Research (2009). Alignment drives employee engagement and productivity. Retrieved from http://www.taleo.com

The Gallup Organization. (2017). State of the global workplace. Retrieved from https://www.kryast.se/wp-content/uploads/2018/10/State-of-the-Global-Workplace_Gallup-R eport.pdf

The Gallup Organization. (2018). The engaged workplace. Retrieved from https://www.gallup.com/services/190118/engaged-workplace.aspx 


\section{Macrothink}

Journal of Management Research

ISSN 1941-899X

2019, Vol. 11, No. 2

Towers Perrin (2003). Working Today: Understanding What Drives Employee Engagement. The 2003 Towers Perrin Talent Report. Retrieved 15 June 2011, from http://www.towersperrin.com/tp/getwebcachedoc?webc=hrs/usa/2003/200309/talent_2003.pd $\mathrm{f}$

Wellins, R. \& J. Concelman. (2005). Creating a culture for engagement. Workforce Performance Solutions. Retrieved August 1, 2005 from www.WPSmag.com.

Yong, S. M. Suhaimi, M. N., Abdullah, S. S., Rahman. S. \& Nik Mat, N. K. (2013). Employee engagement: A study from the private sector in Malaysia. Human Resource Management Research, 3(1), 43-48.

Zenger, J., \& Folkman, J. (2013, June 20). What inspiring leaders do. Retrieved from https://hbr.org/2013/06/what-inspiring-leaders-do 